\title{
A NEW SIMPLIFIED DECISION MAKING SYSTEM FOR SMALL PROJECTS
}

\section{Secărea Tudorel ${ }^{1}$}

\begin{abstract}
Making decisions on funding or not funding projects is the most difficult process in management, especially for the state services that have a limited budget. The aim of this study is to establish a new simplified system for evaluating small projects based on translating all values into economic terms. The new system tries to simplify the Cost-Benefit Analysis (on which it is based) to the bare minimum and still keep a high degree of relevance to the decision-making process. The conclusions were somewhat remarkable, mostly because the system gives accurate and relevant data for comparing projects despite its simplicity. The other big benefit of this system is its simple nature and ease of understanding even for people with no economic studies.
\end{abstract}

The applied part of this paper involves an analysis of real projects in Brasov County - Romania and the results of applying Cost-Benefit Analysis and the new method for evaluating projects.

The paper concludes proposing a new, modern and simple system for improving decision making on small projects.

JEL Classification Numbers: D61, D70; DOI: http://dx.doi.org/10.12955/cbup.v5.970

Keywords: decision making, efficiency, project

\section{Introduction}

Investment decisions represent the main problem of any development strategy. They pose a great obstacle for any management structure, especially in the public sector. A decision has to be made after research results to determine the costs and returns for each option. When an investment decision has to be taken to implement a small project (usually with local impact), one form or another of weighing costs against benefits is involved. The current system used to calculate future benefits versus cost is the Cost-Benefit Analysis. This analysis is best used for big projects that have impacts measurable in monetary terms. In a real-world application, this analysis is too complex for small projects so the aim of this study is to create a new simplified system for evaluating the impact projects will have. The new system will incorporate the core components of the Cost-Benefit Analysis.

\section{The Financial Analysis of a project}

The most used system for analyzing the opportunity of an investment that can be financed by grants consist of six steps (Florio, 2008):

- A presentation and discussion of the socio-economic context and the objectives;

- The clear identification of the project;

- The study of the feasibility of the project and of alternative options;

- Financial Analysis;

- Economic Analysis;

- Risk Assessment.

Our research is based on the Financial Analysis - that is the core of the Cost-Benefit Analysis and which dictates the value of the project in the long term (Dinwiddy, 1996). The financial Analysis is based on the discounted cash flow approach. A system of accounting tables should show cash inflows and outflows related to (Florio, 2008):

- total investment costs;

- total operating costs and revenues;

- financial return on the investment costs: FNPV and FRR;

- sources of finance;

- financial sustainability;

- the latter takes into account the impact of the grant on national (public and private) investors.

For the projects to be funded the Cost-Benefit Analysis must generate results that respect the indicators provided in the Guides for the European Union Programs. This analysis responds to the question: What will be the impact of the project on the target groups in society? (Belli, 2001)

The main purpose of the financial analysis is to use the project cash flow forecasts to calculate suitable net return indicators (Drèze, 1987). In the European Union Guides, a particular emphasis is placed on

\footnotetext{
${ }^{1}$ Transilvania University, Brasov, Romania, e-mail: secarea_t@ yahoo.com
} 
two financial indicators: The Financial Net Present Value (FNPV) and the Financial Internal Rate of Return (FRR) (Florio, 2008).

\section{Investment analysis}

For our study, we took 12 real projects that have been implemented in the Brasov County - Romania with funding from European Union. The projects range from constructions to services and provide the communities with different benefits.

The majority of the Guides, especially those in rural area (The Agency for Financing Rural Investment, 2017) state that the Cost-Benefit Analysis results influence the project selection and funding. In the case of construction projects, the Cost-Benefit Analysis is mandatory, but in the service area this analysis is not used. For services the project is scored on the quality of the proposition and on the estimated impact.

The project performance indicators are the basis for the investment analysis. According to the guidelines the analysis is based on the total investment (which is form from European Grant and local/national contribution), the operating costs and revenues. These inputs are used to calculate the financial net present value (FNPV) and financial internal rate of return (FRR).

The financial net present value is defined as the sum that occurs when the expected investment and operating costs of the project (suitably discounted) are deducted from the discounted value of the expected revenues:

$$
\mathrm{FNPV}=\sum_{t=0}^{n} a_{t} S_{t}=\frac{S_{0}}{(1+i)^{0}}+\frac{S_{1}}{(1+i)^{1}}+\ldots+\frac{S_{n}}{(1+i)^{n}}
$$

Where $S_{t}$ is the balance of cash flow at time $t$ (net cash flow) and $a_{t}$ is the financial discount factor chosen for discounting at time t.

The financial internal rate of return is defined as the discount rate that produces a zero FNPV:

$$
F N P V=\sum\left[S_{t} /(1+F R R)^{t}\right]=0
$$

More specifically, the financial net present value (FNPV), and the financial rate of return (FRR), on the total investment cost, measure the performance of the investment independently of the sources or methods of financing.

The European Guidelines state that for a project to be funded by grant the FNPV must be negative and FRR be smaller than 5\% (Florio, 2008).

In Table 1 below there are the results of the financial analysis for the projects studied.

From this financial analysis of all 12 projects we immediately see that all the FNPV are negative and FRR are smaller than 5\% so is clear that all the projects need European Grant funding. But the problem occurs when we try to differentiate between them. Let's say that we could only finance 6 out of the 12 projects proposed. The financial analysis is a very complex tool from which result are also very complex. For a trained economist, these result can be very helpful, but for ordinary people to understand and make decisions based on this numbers is hard, harder still is the possibility to recalculate these indicators if we tweak the variables that generated them - especially the total investment and the revenues and/or costs.

Also we must take into account that the Cost-Benefit Analysis is used and effective especially for large scale projects. Its complexity is fully justified on massive projects (Pearce, 2006), but for smaller projects with local implication this analysis with all the financial and economic indicators seems too complex. We consider that investments that impact only local communities, smaller than 30.000 people and with simple to estimate costs and benefits need a new type of efficiency measure unit.

\section{Investment opportunity number}

The investment opportunity number is a financial indicator proposed by the author that resulted from the research and analyses of projects and their efficiency - the usage of European Grants - that are a limited resource. This indicator factors in the most important numbers for calculating efficiency of using the funds, but relays on a very simple equation.

The process of calculating this indicator has two stages: 
Stage 1 - calculating the basic indicators from the data that is generated by the project:

$\mathrm{A}=$ (Revenues on 5 Years that includes indirect revenues) / (EU Grant)

$\mathrm{B}=$ (Revenues on 5 Years that includes indirect revenues) $/$ (Operating costs on 5 Years)

$\mathrm{C}=$ (Revenues on 5 Years that includes indirect revenues) / (Local / national contribution)

Table 1: Results of the financial analysis of the studied projects.

\begin{tabular}{|c|c|c|c|c|c|c|c|}
\hline $\begin{array}{c}\text { Project type and } \\
\text { description }\end{array}$ & $\begin{array}{c}\text { Total } \\
\text { investment } \\
\text { costs (RON) }\end{array}$ & $\begin{array}{c}\text { Local / } \\
\text { national } \\
\text { contribution } \\
(\text { RON) }\end{array}$ & $\begin{array}{l}\text { EU Grant } \\
\text { (RON) }\end{array}$ & $\begin{array}{l}\text { Operating } \\
\text { costs }(5 \\
\text { Years) } \\
(\text { RON) }\end{array}$ & $\begin{array}{c}\text { Revenues (5 } \\
\text { Years) - } \\
\text { including } \\
\text { indirect } \\
\text { revenues } \\
(\text { RON) }\end{array}$ & FNPV & FRR \\
\hline $\begin{array}{l}\text { Construction - } \\
\text { Kindergarten } \\
\text { Drăguș }\end{array}$ & $872.494,71$ & $130.874,21$ & $741.620,51$ & $96.919,10$ & $659.350,80$ & $-668.180,10$ & $-24,21$ \\
\hline $\begin{array}{l}\text { Construction - } \\
\text { Sewer system } \\
\text { Rucăr }\end{array}$ & $5.587 .393,43$ & $1.075 .406,43$ & $4.511 .987,00$ & $122.709,78$ & $5.738 .794,00$ & $-4.230 .723,79$ & $-21,80$ \\
\hline $\begin{array}{l}\text { Construction - } \\
\text { Sewer system } \\
\text { Cincu }\end{array}$ & $14.285 .605,24$ & $285.712,10$ & $13.999 .893,14$ & $350.640,00$ & $3.801 .000,00$ & $-9.378 .352,53$ & $-2,23$ \\
\hline $\begin{array}{l}\text { Construction - } \\
\text { Multifunctional } \\
\text { Social Building } \\
\text { Vulcan }\end{array}$ & $2.378 .397,20$ & $495.787,80$ & $1.882 .609,40$ & $459.100,00$ & $605.000,00$ & $-1.667 .544,93$ & $-2,11$ \\
\hline $\begin{array}{l}\text { Construction - } \\
\text { Water adduction } \\
\text { system Voila }\end{array}$ & $749.800,00$ & $224.940,00$ & $524.860,00$ & $324.525,00$ & $683.731,00$ & $-222.419,93$ & 1,42 \\
\hline $\begin{array}{l}\text { Construction - } \\
\text { Building takeoff } \\
\text { ramp for ski } \\
\text { jumping Râșnov }\end{array}$ & $38.380 .000,00$ & $602.000,00$ & $37.778 .000,00$ & $1.331 .970,00$ & $12.490 .000,00$ & 28.774.112,14 & $-3,64$ \\
\hline $\begin{array}{l}\text { Services - Tourist } \\
\text { promotion of Bran }\end{array}$ & $997.836,05$ & $168.112,34$ & $829.723,71$ & $399.134,42$ & $2.993 .508,16$ & N/A & N/A \\
\hline $\begin{array}{l}\text { Services - Tourist } \\
\text { promotion of } \\
\text { Cristian }\end{array}$ & $950.212,00$ & $156.058,70$ & $794.153,30$ & $332.574,20$ & $3.040 .678,40$ & N/A & N/A \\
\hline $\begin{array}{l}\text { Services - Tourist } \\
\text { promotion of } \\
\text { Feldioara }\end{array}$ & $969.618,00$ & $160.485,15$ & $809.132,85$ & $349.062,48$ & $3.296 .701,20$ & N/A & N/A \\
\hline $\begin{array}{l}\text { Services - Tourist } \\
\text { promotion of } \\
\text { Fundata }\end{array}$ & $877.761,28$ & $145.465,99$ & $732.295,29$ & $263.328,38$ & $1.843 .298,68$ & N/A & N/A \\
\hline $\begin{array}{l}\text { Services - Tourist } \\
\text { promotion of } \\
\text { Sânpetru }\end{array}$ & $1.032 .721,60$ & $217.130,62$ & $815.590,98$ & $289.162,05$ & $2.065 .443,20$ & N/A & N/A \\
\hline $\begin{array}{l}\text { Construction and } \\
\text { services - Tourist } \\
\text { promotion of } \\
\text { Râșnov by building } \\
\text { a Tourist Centre }\end{array}$ & $629.164,80$ & $167.023,46$ & $462.141,35$ & $380.990,00$ & $1.062 .000,00$ & $-429.707,42$ & $-2,16$ \\
\hline
\end{tabular}

This first stage takes into account the revenues (the most important indicator) that also contain the indirect revenues (for example for a sewer system the revenues from the taxes and also generated from the improving the health of the community - indirect revenue). The revenues are divided by the Grant the Operating costs and the Local / national contribution to justify the funding better. 
This system of comparing the direct revenues over the main cost indicators has a natural logic, but these 3 numbers can't generate a decision. The three numbers must be united in a simple to understand equation:

A x $35 \%+$ B x $45 \%+C \times 20 \%=$ ION (Investment opportunity number)

\begin{tabular}{|c|c|c|c|c|c|c|c|c|c|}
\hline $\begin{array}{c}\text { Project type } \\
\text { and description }\end{array}$ & $\begin{array}{c}\text { Total } \\
\text { investment } \\
\text { costs }(\mathbf{R O N})\end{array}$ & $\begin{array}{c}\text { Local / } \\
\text { national } \\
\text { contribution } \\
(\text { RON) }\end{array}$ & $\begin{array}{c}\text { EU Grant } \\
\text { (RON) }\end{array}$ & $\begin{array}{l}\text { Operating } \\
\text { costs (5 } \\
\text { Years) } \\
\text { (RON) }\end{array}$ & $\begin{array}{c}\text { Revenues (5 } \\
\text { Years) - } \\
\text { including } \\
\text { indirect } \\
\text { revenues } \\
\text { (RON) } \\
\end{array}$ & $\mathbf{A}$ & B & C & ION \\
\hline $\begin{array}{l}\text { Construction - } \\
\text { Kindergarten } \\
\text { Drăguș }\end{array}$ & $872.494,71$ & $130.874,21$ & $741.620,51$ & $96.919,10$ & $659.350,80$ & 0,89 & 0,41 & 5,04 & 1,50 \\
\hline $\begin{array}{l}\text { Construction - } \\
\text { Sewer system } \\
\text { Rucăr }\end{array}$ & $5.587 .393,43$ & $1.075 .406,43$ & $4.511 .987,00$ & $122.709,78$ & $5.738 .794,00$ & 1,27 & 0,57 & 5,34 & 1,77 \\
\hline $\begin{array}{l}\text { Construction - } \\
\text { Sewer system } \\
\text { Cincu }\end{array}$ & $14.285 .605,24$ & $285.712,10$ & $13.999 .893,14$ & $350.640,00$ & $3.801 .000,00$ & 0,27 & 0,13 & 13,30 & 2,82 \\
\hline $\begin{array}{l}\text { Construction - } \\
\text { Multifunctional } \\
\text { Social Building } \\
\text { Vulcan }\end{array}$ & $2.378 .397,20$ & $495.787,80$ & $1.882 .609,40$ & $459.100,00$ & $605.000,00$ & 0,32 & 0,14 & 1,22 & 0,42 \\
\hline $\begin{array}{l}\text { Construction - } \\
\text { Water adduction } \\
\text { system Voila }\end{array}$ & $749.800,00$ & $224.940,00$ & $524.860,00$ & $324.525,00$ & $683.731,00$ & 1,30 & 0,54 & 3,04 & 1,31 \\
\hline $\begin{array}{l}\text { Construction - } \\
\text { Building takeoff } \\
\text { ramp for ski } \\
\text { jumping Râșnov }\end{array}$ & $38.380 .000,00$ & $602.000,00$ & $37.778 .000,00$ & $1.331 .970,00$ & $12.490 .000,00$ & 0,33 & 0,16 & 20,75 & 4,34 \\
\hline $\begin{array}{l}\text { Services - } \\
\text { Tourist } \\
\text { promotion of } \\
\text { Bran } \\
\end{array}$ & $997.836,05$ & $168.112,34$ & $829.723,71$ & $399.134,42$ & $2.993 .508,16$ & 3,61 & 1,64 & 17,81 & 5,56 \\
\hline $\begin{array}{l}\text { Services - } \\
\text { Tourist } \\
\text { promotion of } \\
\text { Cristian }\end{array}$ & $950.212,00$ & $156.058,70$ & $794.153,30$ & $332.574,20$ & $3.040 .678,40$ & 3,83 & 1,74 & 19,48 & 6,02 \\
\hline $\begin{array}{l}\text { Services - } \\
\text { Tourist } \\
\text { promotion of } \\
\text { Feldioara } \\
\end{array}$ & $969.618,00$ & $160.485,15$ & $809.132,85$ & $349.062,48$ & $3.296 .701,20$ & 4,07 & 1,85 & 20,54 & 6,37 \\
\hline $\begin{array}{l}\text { Services - } \\
\text { Tourist } \\
\text { promotion of } \\
\text { Fundata } \\
\end{array}$ & $877.761,28$ & $145.465,99$ & $732.295,29$ & $263.328,38$ & $1.843 .298,68$ & 2,52 & 1,14 & 12,67 & 3,93 \\
\hline $\begin{array}{l}\text { Services - } \\
\text { Tourist } \\
\text { promotion of } \\
\text { Sânpetru } \\
\end{array}$ & $1.032 .721,60$ & $217.130,62$ & $815.590,98$ & $289.162,05$ & $2.065 .443,20$ & 2,53 & 1,12 & 9,51 & 3,29 \\
\hline $\begin{array}{l}\text { Construction and } \\
\text { services - } \\
\text { Tourist } \\
\text { promotion of } \\
\text { Râşnov by } \\
\text { building a } \\
\text { Tourist Centre }\end{array}$ & $629.164,80$ & $167.023,46$ & $462.141,35$ & $380.990,00$ & $1.062 .000,00$ & 2,30 & 0,97 & 6,36 & 2,51 \\
\hline
\end{tabular}

The percentage for the importance of the individual indicator has been chosen by the author for the local environment. The local / national contribution is smaller in size for this program, so the impact in the bigger picture is diminished to $20 \%$ from the indicator. By contrast the revenues versus operating cost has a bigger importance because the financial support from the EU stops after the initial investment and the local entities must finance the operating of the structure / services.

This percentage could be changed to be adequate for the local environments where they are calculated. For projects where the local / national contribution is greater, the percentage can be adequately changed. 
The period of 5 years had been chosen for this analysis because all the EU Grants stipulate a 5-year period of sustainability for the projects. This period is the minimum in which the project structures must operate according to the initial purpose of the project. Also, this period is best suited for small local projects that usually have a smaller lifespan.

From the Table 2 above we can see that the ION indicator is calculated for all the projects, regarding if they are construction or services based.

Also, this system is easy to transform into a formula in a spreadsheet that can be calculated automatically based on the inputs made. This ease of use and the ability to be understood and calculated by almost everyone regardless of their education, makes this indicator a powerful tool for understanding a project value and comparing it to other projects or even other options of the same project.

The projects can be arranged according to this indicator:

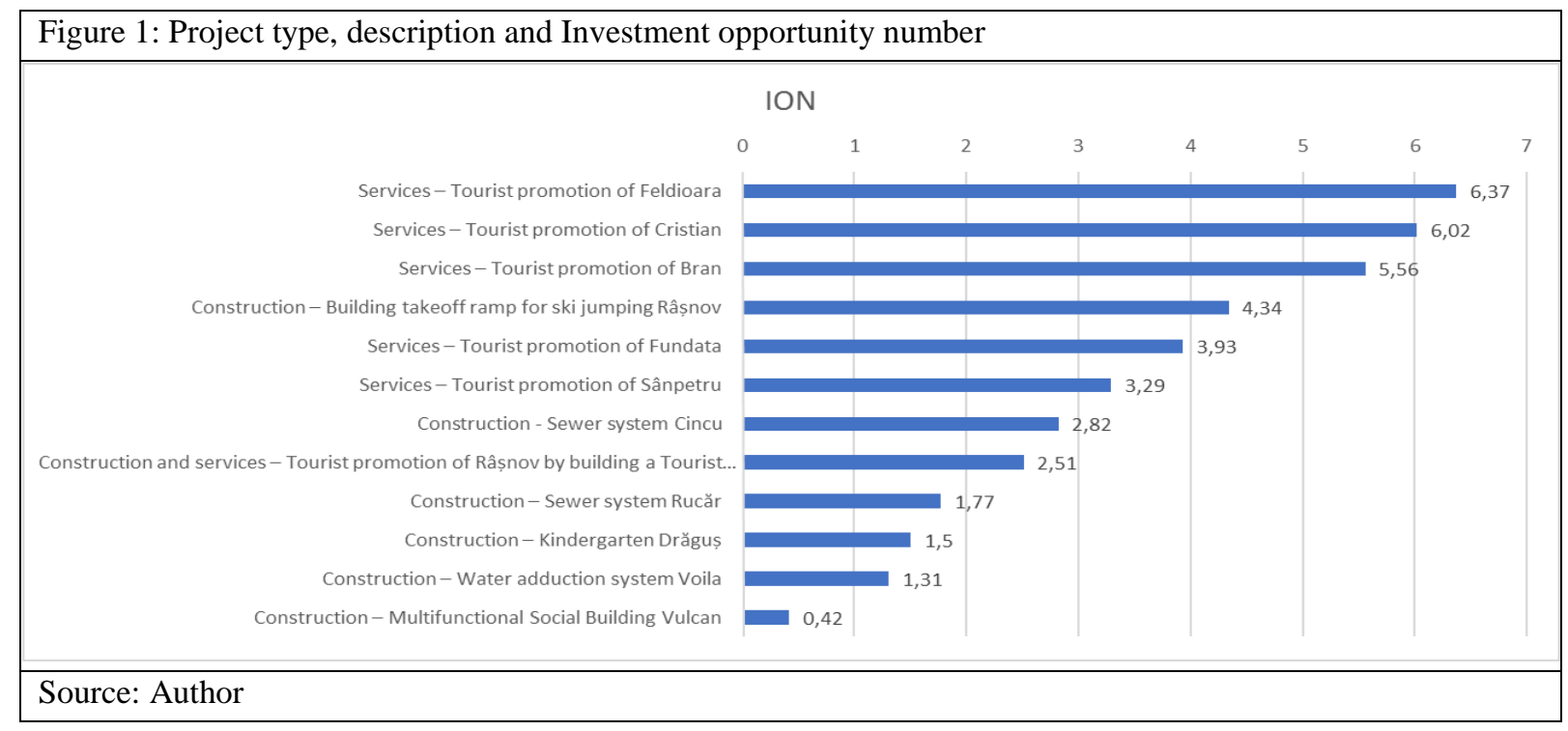

We can observe that the service based projects took the first 3 positions due to the small costs of the projects and the big indirect revenues. All the projects are in direct relation to the economic impact that they had in the local region. We can clearly see that the promotion of tourism and close by, the sewer systems, are investments that have proved the most viable. At the bottom is the Multifunctional Social Building from the Vulcan village that has been proved to be a very minor improvement in the local social and economic sector.

\section{Conclusion}

This indicator is the first step in simplifying the process of decision making for local projects. This analysis, like its more complex counterpart - the Cost-Benefit Analysis - doesn't give the full answer to the viability and economic/social impact of a project. But it does put the basis for reversing the trend in which the whole economic system goes - from simple to complex and even more complex.

It is true that in this simple analysis we didn't take into account all the economic factors and uncertainties, but on local projects, especially ones with lifespans of around 5 years, these externalities could, at least in theory, have a less of an effect on the overall percentage - about $1-5 \%$. So, in the bigger picture these external factors will not affect the final result. Also, the model could be modified to take into account more complex factors if needed.

In conclusion, this tool is created as a response to the growing complexity of decision making, especially for project funding. It is a tool that can be used and customized to the need of the entity that finances or want to implement a project. Its purpose is to make project analysis easier and accessible for everybody. This method is intended for use especially in developing countries to order a large number of alternatives and / or projects in a rapid manner and with a high degree of confidence. We must mention that this indicator is only a part of the decision-making process and it must be used with the other steps in analyzing a project (socio-economic context, the analysis of objectives, study of the 
feasibility, risk assessment). Its importance comes from simplifying the financial analysis and providing a fast, easy to calculate, and dependable indicator for total value over total costs for a project.

\section{Acknowledgment}

All the data from the projects come from 8 years of analyzing and implementing projects for the Brasov County - Romania. Special thanks to the Administrations of: Bran, Cincu, Cristian, Drăguș, Feldioara, Fundata, Râșnov, Rucăr, Sânpetru, Voila, Vulcan.

\section{References}

Belli, P. A. (2001). Economic Analysis of Investment Operations. Analytical Tools and Practical Applications. Washington D.C.: WBI, World Bank.

Boardman A. E., G. D. (2001). Cost-Benefit Analysis concepts and practice 2nd Edition. Upper Saddle River, New Jersey: Pearson Education Prentice Hall.

Boardman A. E., G. D. (2006). Cost-Benefit Analysis: concept and practice 4th Edition. Upper Saddle River, New Jersey: Pearson Prentice Hall.

Dinwiddy C. L., T. J. (1996). Principles of Cost-Benefits Analysis for Developing Countries. Cambridge (UK): Cambridge University Press.

Drèze J., S. N. (1987).The Theory of Cost-Benefit Analysis, in Auerbach. Amsterdam: Handbook of Public Economics, vol.. 2.

Florio M., M. S. (2008). Guide to Cost Benefit Analysis of Investment Projects. Evaluation Unit, DG Regional Policy, European Commission.

Pearce, D. A. (2006). Cost-Benefit Analysis and Environment: Recent Developments. Paris: OECD.

The Agency for Financing Rural Investment. (2017, 03 8). Taken from www.afir.info: http://www.afir.info/ 